\title{
KEBIJAKAN PEMERINTAH DALAM PENGELOLAAN SAMPAH DOMESTIK DI KABUPATEN BANTUL PROPINSI D.I. YOGYAKARTA
}

\author{
Fangga, Surahma Asti Mulasari
}

\author{
Fakultas Kesehatan Masyarakat, Universitas Ahmad Dahlan \\ rahmasti_fkmuad@yahoo.com
}

\section{INTISARI}

Latar Belakang: Sampah adalah hasil dari kegiatan manusia yang dibuang karena tidak berguna, sehingga tidak semua benda padat yang tidak digunakan dan dibuang disebut sampah. Manajemen limbah hanya dipahami oleh sektor publik. Sampah yang dibuang oleh orang-orang dianggap hanya menjadi tugas pemerintah saja untuk ditangani. Sehingga masalah sampah selalu menjadi masalah yang sulit untuk diatasi, jika tidak ada peran komunitas yang aktif dan adanya kesadaran masyarakat itu sendiri. Hal ini diketahui dari laporan bulanan data sampah di Departemen Lingkungan dan dari hasil wawancara peneliti yang dilakukan pada bulan Juni 2012 di Departemen Pekerjaan Umum Bantul. Jumlah orang yang membuang sampah secara illegal ke TPSS Bantul menjadi penyebab limbah tidak dapat dilakukan secara optimal dan lebih sulit untuk mengatasi permasalahan sampah yang ada. Berdasarkan latar belakang di atas, peneliti tertarik untuk mempelajari "Kebijakan Pemerintah dalam Pengelolaan Limbah Domestik Di Bantul.

Metode: Penelitian ini adalah penelitian deskriptif kualitatif. Data diperoleh dari hasil wawancara dari Kepala UPT KP3 DPU dan Sub Sektor dan Sub-Bidang Dokumen LH Kelembagaan Badan Lingkungan Hidup. Instrumen atau alat yang digunakan dalam penelitian ini adalah pedoman wawancara. Data deskriptif dianalisis secara kualitatif dengan mengatakan fenomena yang terjadi dan dianalisis berdasarkan data yang diperoleh dari lapangan. Akuisisi legalitas atau keabsahan penelitian peneliti itu diperoleh dengan triangulasi data.

Hasil: Peraturan yang digunakan dalam pengelolaan sampah rumah tangga di Bantul adalah UU RI No.18 tahun 2008, Permendagri No.33 tahun 2010 dan Peraturan Daerah Bantul Nomor. 15 tahun 2011. Jasa pengelolaan limbah domestik di Bantul dilakukan oleh Departemen Pekerjaan Umum dan BLH. Program pengelolaan sampah di Bantul dilakukan oleh dua lembaga: BLH dan Dinas Pekerjaan Umum. BLH bertugas dalam pembentukan kelembagaan pengelolaan sampah mandiri, sedangkan DPU akan melaksanakan pemerintahan daerah di bidang pekerjaan umum. Alokasi dana yang digunakan dalam pengelolaan limbah domestik dari DAK dan anggaran. Insentif telah diberikan oleh pemerintah Bantul kepada kelompok masyarakat yang berperan aktif dalam pengelolaan sampah rumah tangga.

Kesimpulan: Peraturan yang digunakan dalam pengelolaan sampah rumah tangga di Bantul adalah UU RI No.18 tahun 2008, Permendagri No.33 tahun 2010 dan Peraturan Daerah Bantul Nomor. 15 tahun 2011. Layanan yang diberikan oleh pemerintah kepada masyarakat dalam pengelolaan sampah rumah tangga di Bantul berjalan dengan baik. Kegiatan program pemerintah dalam pengelolaan sampah rumah tangga di Bantul berjalan dengan baik. Alokasi dana yang digunakan dalam pengelolaan sampah rumah tangga di Bantul Rp. 541969 150, -. Dana yang dikeluarkan BLH dari total anggaran tahun 2012 sebesar Rp. 1924580640, .Kebijakan Pemerintah dalam Pengelolaan Sampah Domestik di Kabupaten Bantul Propinsi D.I. Yogyakarta

Insentif yang dikeluarkan dalam pengelolaan sampah rumah tangga di Bantul meliputi: tong sampah, komposter, mesin jahit, mesin pencacah sampah organik, sampah plastik mesin pencacah, dan menggabungkan piha / institusi yang unggul dalam pengelolaan sampah di kompetisi tingkat nasional. 


\begin{abstract}
Background: Garbage is a result of human activity are discarded because it was not useful, so that not all solid objects that are not used and disposed of socalled junk. Waste Management had only understood by the public sector. Waste disposed by people considered to just be the government's job alone to handle. So that the waste problem has always been a difficult problem to overcome, if it is not the role of an active community and awareness of the community it self. It is known from the data monthly report garbage in the Department of the Environment and from interviews the researchers did in June 2012 at the Department of Public Works Bantul. Number of people who throw their garbage into the existing illegal TPSS Bantul cause existing waste management can not be performed optimally and more difficult to overcome the existing problems of garbage. Based on the background above, the researcher is interested in studying "Government Policy in the Domestic Waste Management In Bantul.

Methods: The study was descriptive qualitative. Data obtained on the terms of the interview of Kapala UPT KP3 from DPU and Sub Sector and Sub-Sector Document LH Institutional Capacity of the Environment Agency. Instrument or tool used in this study is an interview guide. Descriptive data were analyzed qualitatively by telling the phenomena that occur and analyzed based on the data obtained from the field. Acquisition of legality or validity of the study the researchers did obtained by triangulation of data.

Results: The regulation is used in the management of domestic waste in Bantul is RI Law No.18 of 2008, No.33 of 2010 Permendagri and Regional Regulation No. Bantul. 15 in 2011. Domestic waste management services in Bantul conducted by the Department of Public Works and BLH. Waste management program in Bantul conducted by two institutions: the BLH and Public Works Department. BLH tasked with the establishment of an independent institutional waste management, while $D P U$ shall carry out the regional administration in the field of public works. Allocation of funds used in the management of domestic waste from DAK and budget. Incentives have been given oelh Bantul government to community groups play an active role in the management of domestic waste.

Conclusion: Regulation is used in the management of domestic waste in Bantul is RI Law No.18 of 2008, No.33 Permendagri in 2010, and the Regional Regulation No. Bantul. 15 in 2011. The services provided by the government to the community in the management of domestic waste in Bantul going well. Program activities by the government in the management of domestic waste in Bantul going well. Allocation of funds used in the management of domestic waste in Bantul Rp. 541 969 150, -. Fund issued BLH of the total budget in 2012 amounted to Rp. 1924580640, -. Incentives are issued in domestic waste management in Bantul include: garbage bins, composter, sewing machine, wheelie bins, organic waste thrasher, thrasher plastic waste, and incorporating the parties / institutions that excel in waste management at the national level competition.
\end{abstract}

Keywords: Government Policy, Waste Management. 


\section{A. PENDAHULUAN}

Meningkatnya tingkat populasi, pertumbuhan ekonomi, urbanisasi yang cepat dan kenaikan standar hidup masyarakat telah mempercepat adanya penumpukan sampah ${ }^{1}$. Sampah adalah masalah yang harus dihadapi oleh masyarakat karena sampah merupakan buangan yang dihasilkan dari aktivitas manusia yang tidak terpakai. Jumlah sampah ini setiap tahun terus meningkat sejalan dan seiring meningkatnya jumlah penduduk dan kualitas kehidupan masyarakat atau manusianya dan disertai juga kemajuan ilmu pengetahuan teknologi yang menghasilkan pula pergeseran pola hidup masyarakat yang cenderung konsumtif ${ }^{2}$.

Pengelolaan sampah telah menjadi isu yang penting selain masalah lingkungan lainnya, terutama untuk kotakota padat penduduk di negara-negara berkembang, oleh karena itu pemerintah perlu menyediakan fasilitas pengelolaan sampah menggunakan teknologi baru agar sampah tersebut dapat ditangani dan tidak lagi menyebabkan polusi lingkungan dan bahaya kesehatan ${ }^{3}$.

Berkaitan dengan permasalahan sampah di Kabupaten Bantul, maka Pemerintah daerah (Pemda) Bantul perlu mencari alternatif pengelolaan sampah. Alternatif tersebut diharapkan dapat mempermudah Pemda Bantul untuk memperoleh kebijakan pengelolaan sampah yang bukan hanya meminimalkan penumpukan sampah tetapi juga mempertimbangkan berbagai aspek terkait, seperti sosial, ekonomi, lingkungan dan teknologi ${ }^{4}$. menghasilkan sampah yang cukup banyak. Kabupaten Bantul merupakan penyumbang sampah ke tiga setelah Kota Yogyakarta dan Kabupaten Sleman dengan jumlah sampahnya sebanyak 9,490 persen sampah ke TPA Piyungan setiap harinya. Sampah yang dihasilkan berasal dari kegiatan pertanian, perkebunan, perdagangan, kantor, dan sebagainya.

Berdasarkan hasil studi pendahuluan yang dilakukan pada bulan Juni 2012 dengan melihat langsung data yang ada di Dinas Lingkungan Hidup dan Dinas Pekerjaan Umum serta kondisi yang ada di masyarakat diketahui, bahwa di Kabupaten Bantul sebagian masyarakatnya telah melakukan upaya pengelolaan sampah secara mandiri. Diantaranya adalah daerah Sedayu, Kasihan, Sewon dan Pleret sedangkan sebagian lagi masih membuang sampahnya secara sembarangan.

Hal ini diketahui dari data laporan bulanan sampah yang ada di Dinas Lingkungan Hidup dan dari hasil wawancara yang peneliti lakukan pada bulan Juni 2012 di Dinas Pekerjaan Umum Kabupaten Bantul. Banyaknya masyarakat yang membuang sampahnya ke TPSS ilegal yang ada di Kabupaten Bantul menyebabkan pengelolaan sampah yang ada belum dapat dilakukan secara maksimal dan semakin sulitnya mengatasi permasalahan sampah yang ada. Berdasarkan latar belakang di atas, maka peneliti tertarik untuk meneliti "Kebijakan Pemerintah Dalam Pengelolaan Sampah Domestik Di Kabupaten Bantul" 
Kebijakan Pemerintah dalam Pengelolaan Sampah Domestik di Kabupaten Bantul Propinsi D.I. Yogyakarta

\section{B. METODE PENELITIAN}

Jenis penelitian ini adalah Deskriptif

Kualitatif, yaitu suatu metode penelitian yang dilakukan dengan tujuan utama membuat gambaran atau deskripsi tentang suatu keadan secara objektif. Penelitian ini dilakukan dengan menempuh langkahlangkah pengumpulan data, analisis data, membuat kesimpulan dan laporan ${ }^{5}$.

Subjek penelitian ini adalah Kepala UPT KP3 dari Dinas Pekerjaan Umum, Sub Bidang Dokumen LH dari Badan Lingkungan Hidup, dan Sub Bidang Pengembangan Kapasitas Kelembagaan dari Badan Lingkungan Hidup Kabupaten Bantul. Objek dalam penelitian ini adalah data sekunder dan dokumen kebijakan pemerintah dalam pengelolaan sampah di.Kabupaten Bantul Yogyakarta.

Instrumen atau alat yang digunakan dalam penelitian ini adalah panduan wawancara. Analisis data dilakukan secara diskriptif kualitatif yaitu dengan menceritakan fenomena-fenomena yang terjadi dan dianalisis berdasarkan datadata yang diperoleh dari lapangan. Data yang telah selesai diolah, kemudian disajikan dalam bentuk narasi, tabel, dan bagan. Perolehan keabsahan atau validitas penelitian yang peneliti lakukan diperoleh dengan cara triangulasi data yaitu melalui triangulasi metode yang berupa wawancara dan observasi, trianggulasi antar peneliti yang menggunakan lebih dari satu orang dalam mengumpulan dan analisis data, dan trianggulasi sumber data yang berupa pengumpulan dokumen, tertulis, gambar atau foto.

\section{HASIL PENELITIAN DAN PEMBAHASAN}

\section{HASIL PENELITIAN}

a. Gambaran Umum Wilayah Kabupaten Bantul

Kabupaten Bantul merupakan salah satu kabupaten dari lima kabupaten atau kota yang ada di Provinsi Daerah Istimewa Yogyakarta (DIY). Berdasarkan data registrasi penduduk pada tahun 2012, jumlah penduduk Kabupaten Bantul adalah 1.020.363 jiwa yang tersebar di 75 desa, 17 kecamatan, dan 933 dusun, dari jumlah tersebut 454.700 jiwa adalah lakilaki dan 454.565 jiwa adalah perempuan dengan jumlah KK sebesar 565.663, maka rata-rata dalam satu KK terdapat 3-4 jiwa.

\section{b. Struktur Organisasi Badan Lingkungan Hidup (BLH) dan Dinas Pekerjaan Umum (DPU) Kabupaten Bantul}

Pemerintah Kabupaten Bantul mempunyai institusi yang memiliki wewenang serta tanggung jawab dalam menangani permasalahan yang berkaitan dengan lingkungan, seperti permasalahan sampah, air limbah, penghijauan serta taman kota, yaitu instansi Badan Lingkungan Hidup (BLH) dan instansi Dinas Pekerjaan Umum (DPU). BLH bertugas melakukan pembentukan kelembagaan pengelolaan sampah mandiri. DPU mempunyai tugas melaksanakan penyelenggaraan pemerintahan daerah di bidang pekerjaan umum.

$\begin{array}{llr}\text { c. Regulasi atau dasar hukum } & \text { hum } \\ \text { pemerintah yang } & \text { digunakan } \\ \text { dalam pengelolaan } & \text { sampah } \\ \text { domestik di } & \text { Kabupaten } & \text { Bantul }\end{array}$ 
Kabupaten Bantul memiliki dasar hukum atau regulasi untuk mengatur setiap kegiatan pemerintahan. Dasar hukum atau regulasi yang digunakan dalam kegiatan pengelolaan persampahan yang ada di Kabupaten Bantul dari hasil wawancara oleh peneliti adalah UU RI No.18 Tahun 2008 tentang pengelolaan sampah, Permendagri No.33 Tahun 2010 tentang pedoman pengolahan sampah, Perda Kabupaten Bantul No.15 Tahun 2011 tentang pengelolaan.

Kutipan wawancara kepada Kepala UPT KP3 dari DinasPU yang berbunyi :

"....regulasi ini sudah berjalan dengan baik. Hal itu ditunjukkan dengan Perda Pengelolaan Sampah tadi sudah dipayungi secara hukum dengan peraturan-peraturan diatasnya..." (Responden 1)

Berdasarkan wawancara diatas dapat dijelaskan bahwa regulasi yang mengatur tentang persampahan di Kabupaten Bantul sudah berjalan dengan baik. Hal itu di buktikan bahwa Perda yang mengatur tentang persampahan di Kabupaten Bantul sudah berdasarkan Undang-Undang yang di atasnya (RUU dan PERMENDAGRI).

\section{d. Pelayanan persampahan di Kabupaten Bantul}

1. Perkiraan Timbulan Sampah Jumlah penduduk di Kabupaten Bantul Tahun 2012 sebanyak 1.020.363 dan menghasilkan $2.550,91 \mathrm{~m}^{3} /$ harinya atau sampah yang dihasilkan 2,5 liter/orang/hari atau 0,625 $\mathrm{Kg}$ /orang/hari.

2. Volume Sampah Total dan Sampah Terangkut
Berdasarkan hasil penelitian diketahui bahwa sebagian besar sampah di Kabupaten Bantul belum terangkut. Sampah yang belum terangkut 597,283 ton per hari, sedangkan yang sudah terangkut hanya 40,443 ton per hari.

3. Jumlah Jejaring Pengelola Sampah di Kabupaten Bantul Jejaring sampah adalah daerah atau sekelompok masyarakat yang dapat mengolah sampahnya dengan mandiri baik dengan menjadikan sampah menjadi kompos, kerajinan atau setidaknya sudah menerapkan 3R dalam pengolahan sampahnya. Kabupaten Bantul mempunyai 38 kelompok bank sampah. Namun tidak semua kecamatan memiliki bank sampah. Hanya 11 kecamatan dari 17 kecamatan di Kabupaten Bantul yang sudah memiliki bank sampah.

4. Rekapitulasi Volume Sampah

Kabupaten Bantul

Rekapitulasi volume sampah ini menunjukkan berapa banyak total sampah yang dikelola oleh pemerintah dan swasta di Kabupaten Bantul pada bulan Januari-Desember tahun 2012. Hasil rekapitulasi sampah di Kabupaten Bantul yang diangkut ke tempat pengolahan sampah terpadu - TPST piyungan dari bulan Januari-Desember tahun 2012 terdapat $15.054 .976 \mathrm{Kg}$ dan sekitar13.706.046 Kg sampah dikelola langsung oleh pemerintah Kabupaten Bantul 
Kebijakan Pemerintah dalam Pengelolaan Sampah Domestik di Kabupaten Bantul Propinsi D.I. Yogyakarta

serta sisanya dikelola oleh swasta.

5. Prosentase volume sampah yang dikelola TPST Piyungan

Tempat Pengolahan Sampah Terpadu (TPST) Piyungan yang berlokasi di Desa Sitimulyo Kecamatan Piyungan Kabupaten Bantul Yogyakarta, digunakan sebagai tempat pembuangan dan pengolahan sampah untuk dua kabupaten dan satu kota yaitu Kabupaten Bantul, Kabupaten Sleman, dan Kota Yogyakarta dengan dibentuknya sekretaris bersama atau Sekberkartamantul. Jumlah volume sampah yang dihasilkan Kabupaten Bantul menempati urutan ke 3 di Provinsi DIY dengan jumlah total 14.881.012 dibawah Kota Yogyakarta dan Kabupaten Sleman.

\section{e. Program Pengolahan Sampah}

Program kegiatan pengolahan sampah merupakan kegiatan pembangunan yang dilakukan oleh BLH dan DPU Kabupaten Bantul di luar pelayanan rutin. Adapun tugas atau program BLH adalah (1) Sistim Pengelolaan Sampah Kota dengan sistem sanitary landfill (2) Teknologi Pengelolaan Sampah yang meliputi pengomposan,daur ulang sampah plastik untui kerajinan, pengumpulan dan pemilahan sampah anorganik, daur ulang styrofoam, dan pelaksanaan 3R. Sedangkan tugas dari Dinas PU adalah pengangkutan sampah mulai dari tempat sampah, dibawa oleh gerobak sampah ke
TPS kemudian dibawa oleh armada truk menuju TPA.

Program kerja tentang pengelolaan sampah di Kabupaten Bantul telah berjalan dengan baik hal itu dibuktikan peran serta masyarakat yang aktif dalam pengelolan sampah. Hal ini sesuai dengan hasil wawancara dengan petugas di Sub Bidang Dokumen LH Badan Lingkungan Hidup yang berbunyi :

" Program pengolahan sampah di Kabupaten Bantul sudah berjalan baik. Hal itu ditunjukkan dengan hampir meratanya jejaring sampah di kecamatan derah Kabupaten Bantul dan peran serta masyarakat yang sudah sangat baik" (Responden 2)

\section{f. Alokasi Dana Pengelolaan Sampah \\ Program kegiatan dalam} pengelolaan sampah di Kabupaten Bantul yang dikelola oleh BLH dan PU memerlukan suatu anggaran atau dana baik dari APBD dan DAK yaitu sebanyak Rp 541.969.150,00.

\section{g. Insentif yang di Keluarkan Dalam Pengelolaan Sampah di Kabupaten Bantul \\ Insentif yang dikeluarkan dalam} pengelolaan sampah di Kabupaten Bantul diantaranya adalah dengan Pemerintah Daerah Kabupaten Bantul memberikan gerobak sampah secara gratis kepada kelompok masyarakat yang memiliki TPS. Selain gerobak sampah, Pemerintah Daerah Kabupaten Bantul juga memberikan, tong sampah, komposter, mesin jahit, mesin pencacah sampah 
organik dan mesin pencacah sampah plastik kepada pihak/lembaga yang mempunyai andil mensukseskan program pengelolaan sampah. Tahun 2012, Pemerintah kabupaten Bantul memberikan 270 tong sampah, 290 komposter, 10 mesin jahit, 41 gerobak sampah, 7 mesin pencacah sampah organik, dan 4 mesin pencacah sampah plastik sebagai insentif kepada pihak - pihak tersebut.

\section{PEMBAHASAN}

\section{a. Regulasi atau dasar hukum} pemerintah yang digunakan dalam pengelolaan sampah domestik di Kabupaten Bantul

Regulasi memiliki peranan yang sangat penting dalam melakukan suatu tindakan kegiatan. Regulasi sebagai pedoman atau dasar hukum yang digunakan dalam mengatur permasalahan sampah yang ada di masyarakat agar dapat diterapkan dan sebagai pembanding sesuai ketentuan pasal yang berlaku.

Dasar hukum yang digunakan oleh pemerintah kabupaten Bantul adalah UUD RI No.18 Tahun 2008 tentang Pengelolaan sampah, Permendagri No.33 Tahun 2010 dan Peraturan Daerah Kabupaten Bantul No 15 tahun 2011 tentang Pengelolaan Sampah. Dalam setiap kegiatan Pemda menggunakan acuan UUD RI No.18 Tahun 2008 untuk menetapkan kebijakan yang terkait mengenai permasalahan sampah yang ada di Kabupaten Bantul. Dasar hukum terkait pengelolaan sampah di Kabupaten Bantul secara konseptual, karena Peraturan Daerah Kabupaten Bantul No 15 tahun 2011 tentang Pengelolaan Sampah sudah dibawah payung hukum dari undang-undang atau peraturan diatasnya. Hal ini sejalan dengan pernyataan dari Kepala UPT KP3 dari Dinas PU.

Peraturan Daerah Kabupaten Bantul No 15 tahun 2011 tentang Pengelolaan Sampah yang mengatur tentang persampahan pada saat ini sudah diterapkan di masyarakat walau belum sepenuhnya dapat dilaksanakan. Hal yang belum dapat dilaksanakan adalah terkait dengan tindak pidana dan sanksinya. Masyarakat yang membuang sampah sembarangan akan di ditindak pidanan kurungan selama 3 bulan atau denda uang sebesar 50 juta rupiah. Hal tersebut tentu akan membuat masyarakat mau untuk bijak dalam mengelola sampah, namun sampai saat ini peraturan tersebut belum maksimal untuk dijalankan ${ }^{6}$.

Manajemen pengelolaan sampah tentu sangat perlu untuk dilakukan oleh pemerintah. Tanpa adanya manajemen, sampah akan menjadi masalah bagi pemerintah daerah karena efeknya langsung pada kesehatan masyarakat, sumber daya alam, dan lingkungan ${ }^{7}$. Untuk mengetahui respon Pmerintah Daerah dalam pengelolaan sampahsampah yang dihasilkan dari berbagai aktivitas manusia, dapat dikelompokan menjadi enam elemen sebagai upya pengelolaan sampah, yakni: Pertama, pengendalian bangkitan (control of generation). Kedua, penyimpanan (storage). Ketiga, pengumpulan (collection). Keempat, pemindahan dan pengangkutan (transfer and transport). Kelima, pemrosesan (processing), dan keenam, yaitu pembungan (disposal) ${ }^{8}$.

Hasil penelitian ini sama dengan hasil penelitian yang dilakukan di Kabupaten Sleman dengan kesimpulan bahwa regulasi yang digunakan di 
Kebijakan Pemerintah dalam Pengelolaan Sampah Domestik di Kabupaten Bantul Propinsi D.I. Yogyakarta

Kabupaten Sleman sudah berjalan dan sudah diterapkan dalam pengelolaan sampah di masyarakat, namun untuk penerapan sanksi yang dilakukan kepada masyarakat yang melakukan pelanggaran belum berjalan sepenuhnya.

\section{b. Pelayanan Pemerintah dalam Pengelolaan Sampah Domestik di Kabupaten Bantul}

Pelayanan persampahan yang diberikan pemerintah kepada masyarakat, bertujuan untuk melayani sampah yang dihasilkan penduduknya, yang secara tidak langsung turut memelihara kesehatan masyarakat serta menciptakan suatu lingkungan yang bersih ${ }^{9}$. Penetapan zona pelayanan sampah dengan mempertimbangkan kepadatan penduduk, fungsi daerah, rencana pembangunan kota (RTRW) dan topografi daerah, menjadi acuan pelaksanaan dalam peningkatan cakupan pelayanan ${ }^{10}$.

Peran pemerintah dalam pengelolaan sampah terpadu di memang sangat penting, namun keterlibatan seluruh stakeholders dalam pengelolaan sampah terpadu akan menjadikan segala sesuatunya menjadi lebih efektif dan efisien. Adapun stakeholders lain yang sangat penting dalam pengelolaan sampah adalah masyarakat, karena masyarakat tersebut yang menghasilkan sampah. Jadi jika masyarakat mau untuk bekerja sama dalam pengelolaan sampah, maka pemerintahpun akan dapat membrikan pelayanan dengan baik ${ }^{11}$.

Untuk itu maka perlu pengaturan pengelolaan sampah khususnya :

Pemilahan sampah pada sumbernya,

tentang perilaku masyarakat dari kebiasaan membuang sampah secara tercampur menjadi sudah terpilah,

memotivasi masyarakat dalam membiasakan memilah sampah pada sumbernya,

meningkatkan peran serta masyarakat dalam merumuskan konsep regulasi di bidang persampahan dalam pengelolaan sampah dengan system pilah.

Merubah pola konsumtif yang boros sampah menjadi hemat sampah, sehingga upaya mengurangi sampah pada sumbernya dapat lebih efektif ${ }^{12}$.

Kegiatan pelayanan persampahan di Kabupaten Bantul meliputi pengangkutan sampah dan pengumpulan sampah. Kegiatan pengangkutan sampah dilakukan sehari sekali yaitu pada siang hari. Jumlah truk pengangkut sampah yang disediakan oleh pemerintah daerah sebanyak 16 truk pengangkut. Setiap truk beroperasi satu kali sehari atau sekali ritasi. Dari kegiatan pengangkutan tersebut diketahui hanya $162 \mathrm{~m}^{3}$ sampah yang terangkut dari 2.389 $\mathrm{m}^{3}$ sampah per harinya. Dari sekian banyak sampah yang tidak dapat terangkut seluruhnya, sebagian sampah-sampah tersebut dibuang secara illegal di berbagai wilayah di Kabupaten Bantul. Hal ini menimbulkan masalah bagi pengelolaan sampah, karena selain mengganggu kenyamanan juga dapat menimbulkan berbagai dampak negatif bagi masyarakat di sekitar lokasi pembuangan.

Kegiatan pengumpulan sampah di Kabupaten Bantul dikonsentrasikan di 111 titik pengumpulan sementara yang tersebar diseluruh kecamatan di kabupaten Bantul. Dari titik pengumpulan sementara, 
sampah diangkut ke tempat pengolahan akhir (TPA) sampah yang terletak di Kecamatan Piyungan. Selain dua kegiatan tersebut, Pemerintah Daerah Kabupaten Bantul juga memberikan gerobak sampah secara gratis pada setiap kelompok masyarakat yang memiliki tempat pembuangan sampah sementara.

\section{c. Program Kegiatan Pemerintah dalam Pengelolaan Sampah Domestik di Kabupaten Bantul}

Program pengelolaan sampah di Kabupaten Bantul dilaksanakan oleh dua instansi, yaitu: Badan Lingkungan Hidup (BLH) dan Dinas Pekerjaan Umum (DPU). BLH bertugas untuk melakukan pembentukan kelembagaan pengelolaan sampah mandiri, sedangkan DPU bertugas melaksanakan penyelenggaraan pemerintahan daerah di bidang pekerjaan umum.

Kegiatan yang dilaksanakan DPU yaitu pengangkutan sampah mulai dari tempat sampah, dibawa oleh gerobak sampah ke TPS kemudian dibawa oleh armada truk menuju TPA. Sebelum sampah-sampah tersebut diangkut ke TPS, masyarakat secara mandiri membuang sampah mereka ke tempat pembuangan sampah mereka masing-masing. Kemudian sampah tersebut diangkut oleh petugas sampah menggunakan gerobak sampah dan dikumpulkan di TPS.Setelah terkumpul di TPS, sampah diangkut oleh truk sampah ke TPA di Piyungan. Pengangkutan sampah dari TPS ke TPA oleh truk sampah, dilakukan sehari sekali.

Kegiatan BLH meliputi: jejaring sampah yaitu membuat pengelolaan sampah mandiri antara lain adalah pengomposan, bank sampah, dan 3R. proses pengomposan adalah upaya untuk merubah dan mendaur ulang sampah sebagai bahan baku membuat kompos.proses pengomposan menjadi penting karena 70-80\% sampah kota adalah bahan organic yang dapa dijadikan kompos $^{17}$. Bank sampah akan memberikan nilai ekonomi sehingga memunculkan pendapatan dari hasil pengelolaan bank sampah serta produk turunan daur ulang sampah ${ }^{13}$.

Program kerja tentang pengelolaan sampah di Kabupaten Bantul telah berjalan dengan baik, hal ini sesuai hasil wawancara dengan Sub Bidang Dokumen LH Badan Lingkungan Hidup. Pengelolaan sampah yang baik adalah apabila adanya peran aktif dari masyarakat ${ }^{18}$.

\section{d. Alokasi Dana dalam Pengelolaan Sampah Domestik di Kabupaten Bantul}

Model sistem Pengolahan Sampah mulai dari timbulan Sampah, pewadahan sampah, pengumpulan sampah, pemindahan sampah, pengangkutan sampah, pembuangan akhir. Tentunya semua proses tersebut membutuhkan pembiayaan atau dana agar semua proses tersebut berjalan dengan lancar. Pembiayaan dalam pengelolaan sampah sangat diperlukan dan pembiayaan ini diperoleh dari iuran masyarakat yang membayar sesuai dengan jumlah yang telah ditentukan oleh pihak pemerintah. Dalam penanganan sampah, aspek pembiayaan merupakan faktor yang menentukan terhadap keberhasilan pengelolaannya $^{14}$.

Komponen utama dalam pembiayaan pengelolaan sampah meliputi 
Kebijakan Pemerintah dalam Pengelolaan Sampah Domestik di Kabupaten Bantul Propinsi D.I. Yogyakarta

biaya pengadaan kendaraan pengangkutan (truk dan gerobak), operasional dan perawatan kendaraan, tenaga kerja (sopir, penyapu jalan, pengangkut sampah, pengawas dan pegawai administrasi) serta sistem pembuangan akhir sampah ${ }^{12}$. Jumlah kendaraan dan tenaga kerja sangat tergantung dari luasnya lokasi dan volume sampah yang dikelola serta kondisi TPS (Tempat Penampungan Sementara). Untuk melaksanakan kegiatan pemilahan sampah tentu dibutuhkan biaya. Biaya ini meliputi: a) biaya investasi, seperti untuk pengadaan gerobak sampah, tong sampah, kantong plastik, kapstok, dll; b) biaya operasional dan pemeliharaan, seperti untuk upah tenaga penggerobak, pembelian stardex, pembelian sekam, biaya rapat koordinasi,dll.

Alokasi dana dalam pengelolaan sampah di Kabupaten Bantul dibiayai oleh Pemerintah Daerah yang bersumber dari Anggaran Pendapatan dan Belanja Daerah (APBD) dan Dana Alokasi Khusus (DAK). Hal ini sesuai dengan bunyi pasal 37 Perda Kabupaten Bantul No. 15 tahun 2011 yaitu: pembiayaan pengelolaan sampah bersumber dari Anggaran Pendapatan dan Belanja Daerahatau sumber pembiayaan lain yang sah.

Total alokasi dana yang dikeluarkan BLH untuk biaya pengelolaan sampah di Kabupaten Bantul tahun 2012 sebesar Rp. 541.969.150,- dari total anggaran BLH tahun 2012 sebesar Rp. 1.924.580.640,-. Alokasi dana tersebut digunakan untuk beberapa program kegiatan, yaitu: Penyediaan prasarana dan sarana pengelolaan persampahan sebesar $\mathrm{Rp}$. 209.350.000, peningkatan operasi dan pemeliharaan sarana dan prasarana persampahan sebesar Rp. 306.356.650, bimbingan teknis persampahan sebesar Rp. 8.000.000, peningkatan peran serta masyarakat dalam pengelolaan persampahan sebesar Rp. 11.012.500, dan penyusunan laporan periodik per bulan sampah harian sebesar Rp. 7.250.000. Alokasi dana di Kabupaten Bantul bisa dikatakan sudah baik karena alokasi dana yang ada bisa disalurkan kepada masyarakat secara maksimal.

\section{e. Insentif dalam Pengelolaan Sampah Domestik di Kabupaten Bantul}

Insentif merupakan penghargaan yang diberikan kepada suatu wilayah yang melakukan program atau kegiatan pengelolaan sampah. Di Kabupaten Bantul, perda yang mengatur tentang pemberian insentif dalam proses pengelolaan sampah terdapat pada Perda Kabupaten Bantul Nomor 15 Tahun 2011 tentang Pengelolaan Sampah Bab VII tentang insentif dan desinsentif.

Reward atau insentif dibutuhkan karena merupakan motivasi dan pendukung profesionalisme dalam bekerja. Hal tersebut perlu mendapatkan perhatian apabila menghendaki kerja yang optimal dari orang yang bekerja untuk perusahaan tersebut. Insentif dapat berupa penghargaan ataupun kompensasi sebagai balasan dalam melakukan sesuatu ${ }^{16}$.

Pasal 29 diatas menyebutkan bahwa Pemerintah Daerah Kabupaten Bantul memberikan insentif/penghargaan kepada pihak yang berjasa dalam pengelolaan sampah baik perseorangan maupun badan usaha/lembaga. Pemberian insentif yang dimaksudkan dalam Perda tersebut dapat berupa subsidi maupun penghargaan. Bentuk pemberian insentif ini tercantum 
JURNAL KESEHATAN MASYARAKAT - VOL. 09 NO. 02/ SEPTEMBER / 2016

dalam pasal 31 Perda Kabupaten Bantul

Nomor 15 Tahun 2011 tentang

D. KESIMPULAN DAN SARAN

Pengelolaan Sampah.

Aplikasi di lapangan, Pemerintah

Daerah Kabupaten Bantul memberikan gerobak sampah secara gratis kepada kelompok masyarakat yang memiliki TPS.

Alasan diberikannya alat-alat tersebut kepada kelompok yang hanya memiliki TPS adalah untuk mengurangi pembuangan sampah ilegal. Selain alatalat yang disebutkan diatas, Pemerintah Daerah Kabupaten Bantul juga memberkantong sampah, komposter, mesin jahit, mesin pencacah sampah organik dan mesin pencacah sampah plastik kepada pihak/lembaga yang mempunyai andil mensukseskan program pengelolaan sampah. Mesin-mesin tersebut diberikan kepada pihak/lembaga yang memiliki pengelolaan sampah yang sudah maju dan mandiri yang dimaksudkan agar pihak/lembaga tersebut lebih efektif dalam menjalankan pengelolaan sampah mereka. Tahun 2012, Pemerintah Kabupaten Bantul memberikan 270 tong sampah, 290 komposter, 10 mesin jahit, 41 gerobak sampah, 7 mesin pencacah sampah organik, dan 4 mesin pencacah sampah plastik sebagai insentif kepada pihak pihak tersebut.

Pemberian insentif pengelolaan sampah oleh Pemerintah Kabupaten Bantul tidak hanya berupa alat atau mesin seperti yang disebutkan diatas, namun juga berupa mengikutsertakan pihak/lembaga pada kompetisi yang diadakan pada tingkat nasional.

1. Kesimpulan

a. Regulasi yang digunakan dalam pengelolaan sampah domestik di Kabupaten Bantul adalah UU RI No.18 Tahun 2008, Permendagri No.33 Tahun 2010, dan PERDA Kabupaten Bantul No. 15 tahun 2011.

b. Pelayanan yang diberikan oleh pemerintah kepada masyarakat dalam pengelolaan sampah domestik di Kabupaten Bantul berjalan dengan baik.

c. Program kegiatan yang dilakukan pemerintah dalam pengelolaan sampah domestik di Kabupaten Bantul berjalan dengan baik.

d. Alokasi dana yang digunakan dalam pengelolaan sampah domestik di Kabupaten Bantul sebesar Rp. 541.969.150,$(28,16 \%)$. Dana tersebut di keluarkan dari total anggaran BLH tahun 2012 yang sebesar Rp. 1.924.580.640,-

e. Insentif yang dikeluarkan dalam pengelolaan sampah domestik di Kabupaten Bantul berupa: tong sampah, komposter, mesin jahit, gerobak sampah, mesin pencacah sampah organik, mesin pencacah sampah plastik, dan mengikutsertakan pihak/lembaga yang berprestasi dalam pengelolaan sampah pada lomba tingkat nasional.

2. Saran

a. Bagi Pemda Bantul (BLH dan DPU) agar menegakkan regulasi tentang pengelolaan sampah khususnya dalam hal sanksi 
Kebijakan Pemerintah dalam Pengelolaan Sampah Domestik di Kabupaten Bantul Propinsi D.I. Yogyakarta

pidana terhadap para pelanggar agar para pelanggar yang sering membuang sampah liar terjadi efek jera untuk membuang sampah sembarangan.

b. Bagi masyarakat Kabupaten Bantul agar meningkatkan kesadaran dalam pengelolaan sampah sehingga terwujud lingkungan yang bersih dan sehat.

c. Kepada Mahasiswa Fakultas Kesehatan Masyarakat Universitas Ahmad Dahlan Khususnya Prodi Ilmu Kesehatan Masyarakat, perlu mengadakan suatu kegiatan pendekatan serta penyuluhan terhadap masyarakat Kabupaten Batul untuk selalu menjaga kebersihan dan meningkatkan kesadaran akan perilaku yang tidak sembarangan membuang sampah yang dapat menimbulkan permasalahan bagi masyarakat itu sendiri dan pemerintah tentunya. Masyarakat perlu diberikan suatu pengertian dan pelatihan tentang pengelolaan sampah serta manfaat dari pengelolaan sampah tersebut sehingga dengan pengertian, pelatihan tersebut masyarakat sadar bahwa sampah bukan lagi barang yang tidak berguna tetapi dapat menjadi sumber penghasilan bagi mereka.

\section{DAFTAR PUSTAKA}

Aditya, Sarwono, Rozikin, 2010, "Sinergitas Stakeholders Untuk Administrasi Publik Yang
Demokratis Dalam Perspektif Teori Governance (Studi Pada Tempat Pengelolaan Sampah Terpadu Mulyoagung Bersatu Kecamatan Dau, Kabupaten Malang)", Jurnal Administrasi Publik, 2 (3), hal. 407-413.

and Management in Kolkata, India", International Journal of Emerging Technology and Advanced Engineering, 3 (2), pp. 147-152.

Das, S., Bhattacharyya, B., 2013, "Municipal Solid Waste Characteristics

Ernawati, D., Budiyanti, S., Masykuri, M., 2012, "Analisis Komposisi, Jumlah Dan Pengembangan Strategi Pengelolaan Sampah Di Wilayah Pemerintah Kota Semarang Berbasis Analisis Swot", Jurnal Ekosains, 4 (2), hal. 13-21.

Galileo, R., 2012, “Kebijakan Pemerintah Daerah Dalam Pengelolaan Sampah Pasca Penetapan UU No. 18 Tahun 2008", Jurnal Demokrasi \& Otonomi Daerah, 10 (1), hal. 1-66.

Guerrero, L.A.,Maas, G.,Hogland, W., 2013, "Solid Waste Management Challenges For Cities In Developing Countries", Journal Elsevier, 33, pp. 220-232.

Hariastuti, N., 2013, "Pemodelan Sistem Normatif Pengelolaan Sampah Kota”, Jurnal IPTEK, 17 (1), hal. 61-72.

Iman, Kustiwan, 2012, "Keberlanjutan Pengelolaan Sampah Berbasis 
Masyarakat di Kelurahan

Tamansari Kota Bandung", Jurnal

Perencanaan Wilayah \& Kota, 2 (2), hal. 283-290.

Irawan, B., 2013, "Penerapan Sangsi Administrasi Dalam Membuang Sampah Pada Siang Hari Di Kota Samarinda (Studi Kasus Di Kelurahan Sungai Dama)", Jurnal Beraja Niti 2 (8), hal. 1-21.

Kurniawan, T., 2003, "Manajemen Kota Berkelanjutan Di Indonesia : Indicator Dalam Upaya Mengembangkan Kebijakan Kota Berkelanjutan Oleh Pemerintah Koa Di Indonesia", Jurnal Bisnis \& Birokrasi, 11 (2), hal. 28-36.

Mulasari, Husodo, Muhadjir, 2014, "Kebijakan Pemerintah dalam Pengelolaan Sampah Domestik", Jurnal Kesehatan Masyarakat Nasional, 8 (8), hal. 404-410.

Murdiningsih, 2012, "Implementasi Kebijakan Pengelolaan Persampahan Di Dinas Kebersihan Kota Manado", Jurnal Administrasi Publik, 2 (3), hal. 160-170.

Notoadmodjo, 2007., Kesehatan Masyarakat Ilmu Dan Seni, Rineka Cipta, Jakarta. Hal 187-188.

Sahwan, Irawati, Suryanto, 2004, "Kebijakan Pemerintah dalam Pengelolaan Sampah Domestik", Jurnal Teknik Lingkungan, 5 (12), hal. 134-139.

Slamet, J.S., 2007, Kesehatan Lingkungan, Gadjah Mada
Universty Press, Yogyakarta. Hal. 154.

Surjandari, I., Hidayanto, A., Supriatna, A., 2009, "Model Dinamis Pengelolaan Sampah Untuk Mengurangi Beban Penumpukan”, Jurnal Teknik Industri, 11 (2), hal. 134-147.

Widodo dan Susanto, 2009, "Kapasitas Masyarakat dalam Pengelolaan Sampah Kota (Studi masyarakat Jakarta, tangerang, bekasi, Depok)", Jurnal Teknik Lingkungan, Vol 10, Hal. 329-330.

Yansen, I. W., Arnatha, I. M., 2012, "Analisis Finansial Sistem Pengelolaan Sampah Di Wilayah Kecmatan Mengwi Kabupaten Badung", Jurnal Ilmu Teknik Sipil, Vol.16 No. 1, Hal 107-116. 
